\title{
Influence of problem-based learning combined with community-based education and service as an integral part of the undergraduate curriculum on speciality and rural workplace choices
}

Citation for published version (APA):

Amalba, A. (2018). Influence of problem-based learning combined with community-based education and service as an integral part of the undergraduate curriculum on speciality and rural workplace choices. [Doctoral Thesis, Maastricht University]. Datawyse / Universitaire Pers Maastricht. https://doi.org/10.26481/dis.20181220aa

Document status and date:

Published: 01/01/2018

DOI:

10.26481/dis.20181220aa

Document Version:

Publisher's PDF, also known as Version of record

Please check the document version of this publication:

- A submitted manuscript is the version of the article upon submission and before peer-review. There can be important differences between the submitted version and the official published version of record. People interested in the research are advised to contact the author for the final version of the publication, or visit the DOI to the publisher's website.

- The final author version and the galley proof are versions of the publication after peer review.

- The final published version features the final layout of the paper including the volume, issue and page numbers.

Link to publication

\footnotetext{
General rights rights.

- You may freely distribute the URL identifying the publication in the public portal. please follow below link for the End User Agreement:

www.umlib.nl/taverne-license

Take down policy

If you believe that this document breaches copyright please contact us at:

repository@maastrichtuniversity.nl

providing details and we will investigate your claim.
}

Copyright and moral rights for the publications made accessible in the public portal are retained by the authors and/or other copyright owners and it is a condition of accessing publications that users recognise and abide by the legal requirements associated with these

- Users may download and print one copy of any publication from the public portal for the purpose of private study or research.

- You may not further distribute the material or use it for any profit-making activity or commercial gain

If the publication is distributed under the terms of Article $25 \mathrm{fa}$ of the Dutch Copyright Act, indicated by the "Taverne" license above,

Download date: 26 Apr. 2023 


\section{Summary}





\section{Summary}

The overall aim of this thesis was to investigate the influence of Problem-based learning (PBL) with Community-based education and service (COBES) as part of an undergraduate medical curriculum on specialty and rural workplace choices. The thesis investigated the contribution of COBES in helping to address the mal-distribution of medical workforce in the rural areas in Ghana specifically and sub-Saharan Africa in general.

\section{Introduction}

An important challenge for today's higher education is the development and implementation of instructional practices that will allow students acquire and apply the skills and knowledge they attain efficiently. The expectation of society in contemporary higher education is that graduates should have, not only a robust knowledge base, but also be able to apply this knowledge to solve problems in an efficient way.

Many educational innovations have been implemented with the hope of achieving to teach students the necessary knowledge base, and habit technical and non-technical skills to address the expectation of contemporary society.

Such educational innovations included, for example, the introduction of Problem-Based Learning (PBL) methodology and Community-Based Education and Service (COBES). COBES prepares health professionals to address the health needs of a community. The emphasis is on health promotion and disease prevention, not treatment; the focus is on populations rather than individuals.

Community-Based Education and Service, which has nowadays become widely accepted as an important innovation in undergraduate medical training, was at the time of its introduction considered as one among many the educational intervention to address local, rural community health needs, so its importance at the time is clearly acknowledged in contemporary medicine

The Chapters in this thesis provide answers to the general research questions: 1 ) Will the introduction of an innovative curriculum such as PBL with COBES help attract health professionals to the rural areas and also assist in addressing the inequity of doctors in the rural Ghana? 2) a) what benefits does COBES bring to the community, students and staff of the health facilities b) what are the challenges of COBES to stakeholders and c) what contribution of other stakeholders together with the community to improve and sustain COBES for the mutual benefits of both. 
In the Chapters we present findings obtained from both qualitative and quantitative research performed from 2013 to 2018 that provided insights into the benefits of COBES and rural outreach programmes to the rural community, students and other stakeholders in that community.

A brief summary of the different Chapters is consecutively presented below.

\section{Chapter 1}

The introductory Chapter of this thesis outlined a detailed historical background of medical education from the pre-Flexner period of apprenticeship model of medical training, the Flexner era of biomedical approach to medical training and a new approach integrating community-oriented medical education. It looked at the expectations of society in contemporary higher education with the view that medical graduates would possess adequate knowledge and skills to address the needs of the population it serves. The Chapter subsequently introduced the theme of ProblemBased Learning/Community-Based Education and Service in undergraduate medical education. Furthermore, it outlined the theoretical underpinning of PBL and COBES from the field of socio-constructive and social learning theories

Finally, an overview of the literature on the importance of rural outreach programmes based on evidence of previous studies from the developed and the developing world were also presented. In short, the international literature provides evidence of the influence of COBES and other rural outreach programmes in addressing the disparity of medical workforce in remote communities. However, the evidence from the settings of the developed countries may not be generalisable enough to the settings of subSaharan Africa to design educational interventions to address the mal-distribution of rural workforce in sub-Saharan Africa. These findings provided the basis and justification for the studies on COBES summarised in the next sections.

\section{Chapter 2}

In Chapter 2 we presented a systematic literature review of studies conducted in Africa and published in peer-reviewed journals on the role of COBES and rural outreach programmes in addressing the disparity of rural-urban medical workforce. The review identified only 18 published peer-reviewed articles from Uganda, South Africa, Ghana, Nigeria, Tanzania, Democratic Republic of Congo and Botswana. The already small number of published articles was furthermore limited to a few countries in Africa, thus making research output from this geographic area woefully inadequate. Most countries 
in Africa are yet to embrace COBES and rural outreach programmes as an important educational intervention to train doctors and other health professionals, who are willing and able to work in remote areas of the country. It is also important to note that there is cumulative evidence from the few African countries that have incorporated COBES and rural outreach programmes as part of the undergraduate medical curriculum which has shown that exposing students to the rural areas as part of their training positively affects their eventual practice location. Studies from these countries point to the fact that training health profession students in the rural community could bring equity in the distribution of health professionals to the benefit of the rural people.

\section{Chapter 3}

The findings in Chapter 3 revealed the usefulness and benefits of COBES to the rural community, students and staff of the health facilities. The community members have acknowledged that benefits such as the improvement of their understanding and awareness of health matters, the increase in their health seeking behaviours were a result of the community members' interactions with the students during the rural outreach programme.

The students opined that the rural communities serve as an authentic learning environment where they were confronted with various kinds of diseases and that they also had the opportunity to "practice" some of the skills learnt in medical school on real patients. This, they said assisted them to improve on their clinical skills and also their knowledge base of different types of diseases. They also indicated that the rural rotation was beneficial to them in that they were able to adjust and adapt to rural enabling them to cope with living in the rural communities. In this way, they get acclimatised to the living conditions in the rural areas and this eventually minimises the shock of transition when they are eventually sent back as doctors to similar communities to work after graduation.

The staff of the health facilities do benefit from services provided by the students at these facilities. In practice, the students, assume the role of health staff by complementing the shortages of health workers at the health facilities and reducing the waiting time for patients, thus addressing some of the manpower gaps at the health facilities. 


\section{Chapter 4}

In Chapter 4, we discussed the findings of the influence of role models during COBES and how this affects student trainees' career paths. The findings in this chapter showed that students identified personal, teaching and professional attributes that they think would have an impact on their career paths. These were the attributes and qualities identified by the students they valued in persons they observed and perceived as role models during COBES. In general, a role model during COBES coaches, mentors, and helps prepare medical students towards choosing a professional career, and this assists to shape the students' professional identity, create awareness of their professional responsibility and their entry into the work place as doctors.

Students identified health workers, community leaders such the assembly members, chiefs and faculty members from the university as persons who could serve as role models in the rural community.

\section{Chapter 5}

In Chapter 5, we discussed the results of the effect of COBES on medical graduates' choice of specialty and their willingness to work in the rural areas of Ghana. The findings of this study showed that when students from the cities and urban towns are exposed early to COBES during their medical training, they develop the willingness to work in the rural areas despite their city upbringing. During their stay in the communities, they observe the poverty levels in the communities and the difficulties less privileged members of the community face in accessing quality healthcare. These account for the desire of the graduates to help the communities to improve upon the status of the healthcare system.

\section{Chapter 6}

Chapter 6 focused on the factors that influence medical doctors to practice in the rural areas of Ghana. The findings of this study indicated that medical doctors choose to practice in the rural areas because they want to acquire more skills and experience. Furthermore, most of the doctors, especially those trained at UDS-SMHS indicated that their undergraduate medical curriculum prepared them well for rural practice. However, they indicated that social barriers, access to resources, educational challenges, family and cultural-related factors were some of the deterrents that negatively affected doctors from choosing to practice in the rural communities. They 
made suggestions to improve and sustain COBES by calling on the Government, Ministries of Health and Education to offer sponsorship packages to medical graduates in the rural areas wishing to pursue postgraduate training. Also, they urged the Government to send senior specialists and consultants to some of the district hospitals, so as to make the district hospital eligible for accreditation for training medical officers.

\section{Chapter 7}

In Chapter 7, we discussed whether trainees' preferences regarding the place of work is influenced by the type of curriculum used in their training. The findings showed that students from University of Ghana School of Medicine and Dentistry (UGSMD), though trained with a limited rural outreach programme, believed that it would be useful in having part of their training in the rural communities. The students from UGSMD, however, indicated that lack of rural experience during their medical school training would deter them from wanting to work in the rural communities after graduating. The students from UDS-SMHS suggested that rural exposure as part of the curriculum adequately prepared them for rural practice after graduating.

As a way of improving the undergraduate medical curriculum which incorporates COBES, students from UGSMD requested the introduction of community-based education activities such as rural outreach programmes to improve the undergraduate curriculum. However, UDS-SMHS students listed strategies such as proper orientation of students about COBES and selection of well-resourced and well-equipped health centres as a way of improving the already implemented rural training.

\section{Chapter 8}

In Chapter 8, a general discussion of the findings of the different studies addressing the research questions formulated in chapter 1 is provided making references to relevant literature and how they contribute in answering the research questions. Conclusions are drawn thereafter; the strengths of the studies highlighted, and limitations of the studies identified. In addition, the Chapter ends with suggestions for further research and implications for practice. 

Samenvatting 



\section{Samenvatting}

Het algemene doel van dit proefschrift was om te onderzoeken welke invloed Probleemgestuurd Onderwijs (PGO) in combinatie met gemeenschapsgericht(e) onderwijs en dienstverlening (COBES)* binnen een curriculum van de bachelor Geneeskunde heeft op de keuze van specialisme en om op het platteland te werken. Het proefschrift onderzocht welke bijdrage COBES levert aan de aanpak van de ongelijke spreiding van medisch personeel op het platteland in sub-Sahara Afrika en in het bijzonder in Ghana.

\section{Introductie}

Een belangrijke uitdaging voor het hoger onderwijs van vandaag de dag is om onderwijspraktijken te ontwikkelen en in te voeren die studenten in staat stellen de kennis en vaardigheden die zij opdoen op efficiënte wijze aan te leren en toe te passen. De eis die de samenleving stelt aan het hedendaagse hoger onderwijs is dat afgestudeerden niet alleen een gedegen kennisbasis moeten hebben, maar ook in staat moeten zijn deze kennis in te zetten voor het op efficiënte wijze oplossen van problemen.

Er zijn veel onderwijsvernieuwingen ingevoerd met de hoop studenten de nodige kennisbasis te geven, alsook de technische en niet-technische vaardigheden die hen in staat stellen aan de eisen van hedendaagse samenlevingen te voldoen.

Voorbeelden van zulke onderwijsvernieuwingen zijn de introductie van de Probleemgestuurd-Onderwijs-(PGO)-methode en gemeenschapsgericht(e) onderwijs en dienstverlening (COBES). COBES traint zorgprofessionals om aan de zorgbehoeften van een gemeenschap te beantwoorden. De nadruk ligt daarbij niet op behandeling, maar op gezondheidsbevordering en ziektepreventie; ook ligt de nadruk op bevolkingsgroepen in plaats van op individuen.

COBES, wat tegenwoordig algemeen aanvaard wordt als een belangrijke vernieuwing in de bacheloropleiding Geneeskunde, werd ten tijde van de introductie beschouwd als een van de vele onderwijsinterventies die ten doel hadden aan de zorgbehoeften van de lokale en plattelandsgemeenschap te beantwoorden; het belang van destijds wordt dus duidelijk erkend in de hedendaagse geneeskunde.

De Hoofdstukken in dit proefschrift geven antwoord op de algemene onderzoeksvragen: 1) Zal de introductie van een vernieuwend curriculum zoals PGO in combinatie met COBES helpen om zorgprofessionals naar de plattelandsgebieden te trekken en ook bijdragen aan de aanpak van de ongelijke spreiding van artsen in landelijk Ghana? 2a) 
Welke voordelen heeft COBES voor de gemeenschap, studenten en stafleden van de zorginstellingen? 2b) Welke uitdagingen brengt COBES met zich mee voor de betrokkenen? 2c) Hoe dragen betrokkenen in samenwerking met de gemeenschap bij aan de verbetering en de instandhouding van COBES waar zij beiden belang bij hebben? In de Hoofdstukken van het proefschrift presenteerden we bevindingen die we verkregen uit zowel kwalitatief als kwantitatief onderzoek dat van 2013 tot 2018 is uitgevoerd en dat inzicht bood in de voordelen van COBES en plattelandshulpverleningsprogramma's voor de plattelandsgemeenschap zelf, studenten en andere betrokkenen in die gemeenschap.

Hieronder worden de verschillende Hoofdstukken achtereenvolgens kort samengevat.

\section{Hoofdstuk 1}

Het inleidend Hoofdstuk van dit proefschrift gaf een gedetailleerd overzicht van de geschiedenis van het medisch onderwijs, van de periode vóór Flexner's leermeestergezelmodel van medisch opleiden tot het Flexner-tijdperk waarin de biomedische benadering van medisch opleiden centraal stond en een nieuwe benadering waarbij gemeenschapsgericht medisch onderwijs geïntegreerd wordt. Laatstgenoemde keek naar de eisen die de samenleving stelt aan het hedendaagse hoger onderwijs met het idee dat afgestudeerde basisartsen in dat geval over voldoende kennis en vaardigheden zouden beschikken om aan de behoeften van de bevolking die zij zouden dienen, tegemoet te komen. Vervolgens introduceerde het Hoofdstuk het thema van Probleemgestuurd Onderwijs/ gemeenschapsgericht(e) onderwijs en dienstverlening in de bacheloropleiding Geneeskunde. Voorts beschreef het de theoretische onderbouwing van PGO en COBES vanuit de sociaal-constructieve en sociale leertheorieënvelden.

Ten slotte werd een overzicht gegeven van de literatuur over het belang van plattelandshulpverleningsprogramma's dat met bewijs van voorgaande studies uit ontwikkelde en ontwikkelingslanden werd gestaafd. Kortom, de internationale literatuur levert bewijs dat COBES en andere plattelandshulpverleningsprogramma's de ongelijke spreiding van medisch personeel in afgelegen gemeenschappen helpen aanpakken. Het is echter mogelijk dat het bewijs uit de ontwikkelde-landen-settings niet voldoende generaliseerbaar is naar de settings van sub-Sahara Afrika om daar de ongelijke spreiding van medisch personeel in de subregio aan te pakken. Deze bevindingen vormden de basis en rechtvaardiging voor de studies over COBES zoals in de volgende alinea's wordt samengevat. 


\section{Hoofdstuk 2}

In Hoofdstuk 2 presenteerden we een wetenschappelijk literatuuronderzoek van in Afrika verrichte en in "peer-reviewed" tijdschriften gepubliceerde studies over de rol van COBES en plattelandshulpverleningsprogramma's bij het recht trekken van de wanverhouding tussen het medisch personeel op het platteland en in de steden. Het onderzoek vond slechts 18 gepubliceerde van dergelijke artikelen, en wel uit Oeganda, Zuid-Afrika, Ghana, Nigeria, Tanzania, de Democratische Republiek Congo en Botswana. De onderzoeksoutput uit dit geografische gebied is dus volstrekt ontoereikend. De meeste landen in Afrika moeten COBES en plattelandshulpverleningsprogramma's nog accepteren als een belangrijke onderwijsinterventie waarmee artsen en andere zorgprofessionals opgeleid kunnen worden opdat zij bereid en in staat zijn in afgelegen gebieden van hun land te werken. Het is ook van belang te vermelden dat het bewijs uit de paar Afrikaanse landen die COBES en andere plattelandshulpverleningsprogramma's wel in het bachelor-Geneeskunde-curriculum hebben opgenomen, dat dergelijke programma's een positieve invloed hebben op de locatie waar de studenten in de toekomst uiteindelijk werkzaam zullen zijn, zich opstapelt. Studies uit deze landen wijzen op het feit dat het opleiden van gezondheidszorgstudenten in de plattelandsgemeenschap de ongelijke spreiding van zorgprofessionals recht kan trekken waar de plattelandsbevolking voordeel bij heeft.

\section{Hoofdstuk 3}

De bevindingen in Hoofdstuk 3 lieten zien wat het nut en de voordelen waren van COBES voor de plattelandsgemeenschap, studenten en stafleden van de zorginstellingen. De gemeenschapsleden gaven aan dat voordelen zoals een verbeterd begrip en bewustzijn van gezondheidszaken en een toename in hun ziektegedrag een gevolg waren van hun interacties met studenten tijdens het plattelandshulpverleningsprogramma.

De studenten waren van mening dat de plattelandsgemeenschappen als authentieke leeromgeving dienden waarbinnen zij met allerlei ziekten werden geconfronteerd en dat zij ook de kans kregen om enkele van de tijdens de geneeskundeopleiding opgedane vaardigheden te "oefenen" op echte patiënten. Volgens hen hielp dit hen om hun klinische vaardigheden, evenals hun kennisbasis van de verschillende soorten ziekten te verbeteren. Ook gaven ze aan dat de praktijkervaring op het platteland nuttig voor hen was omdat zij zich daardoor leerden aan te passen aan het leven op het 
platteland, wat ertoe leidde dat zij het leven onder de plattelandsgemeenschappen beter aan konden. Op deze manier raakten zij gewend aan de leefomstandigheden op het platteland, wat op den duur de overgangsschok verkleint wanneer zij na het afstuderen teruggezonden worden naar vergelijkbare gemeenschappen om daar als arts te werken.

Ook de stafleden van de zorginstellingen hadden baat bij de diensten die de studenten verleenden in deze instellingen. In de praktijk namen studenten de rol van gezondheidswerker op zich door tekorten aan gezondheidswerkers in de zorginstellingen aan te vullen en de wachttijd voor patiënten te verkorten. Daarmee hielpen zij een deel van het tekort aan arbeidskrachten in de zorginstellingen op te vangen.

\section{Hoofdstuk 4}

In Hoofdstuk 4 bespraken we de bevindingen ten aanzien van de invloed van rolmodellen tijdens COBES, en hoe zij het verdere loopbaantraject van studenten/ aiossen kunnen beïnvloeden. De bevindingen uit dit hoofdstuk laten zien dat studenten persoonlijke, didactische en professionele eigenschappen onderscheidden waarvan zij dachten dat deze van invloed zouden zijn op hun loopbaantraject; met andere woorden, eigenschappen en kwaliteiten die door studenten als waardevol werden aangemerkt en die zij hadden waargenomen in mensen die zij tijdens COBES hadden geobserveerd en als rolmodel beschouwden. Over het algemeen is een rolmodel tijdens COBES zowel coach als mentor en helpt hij/zij geneeskundestudenten zich voor te bereiden op hun latere loopbaankeuze, wat studenten weer helpt hun professionele identiteit vorm te geven, hen bewust te maken van hun professionele verantwoordelijkheid en hun intrede te maken als arts op de werkplek.

Studenten gaven aan dat gezondheidswerkers, gemeenschapsleiders zoals leden van de assemblee, hoofden en faculteitsleden van de universiteit als rolmodel konden dienen in de plattelandsgemeenschap.

\section{Hoofdstuk 5}

In Hoofdstuk 5 bespraken we de resultaten betreft de invloed van COBES op de specialismekeuze van afgestudeerde basisartsen en hun bereidheid om op het platteland van Ghana te werken. De bevindingen van deze studie toonden aan dat wanneer studenten uit de steden en grotere gemeenten al vroeg in de geneeskundeopleiding worden blootgesteld aan COBES, ze de bereidheid ontwikkelen om in de plattelandsgebieden te werken, ondanks hun stedelijke opvoeding. Tijdens 
hun verblijf in de gemeenschappen aanschouwden zij het armoedeniveau en de moeilijkheden die de kansarmere gemeenschapsleden ondervonden bij het ontvangen van kwalitatief goede zorg. Dit verklaart waarom afgestudeerden de wens hadden om de gemeenschappen te helpen de status van het zorgstelsel te verbeteren.

\section{Hoofdstuk 6}

Hoofdstuk 6 richtte zich op de factoren die artsen inspireren om op het platteland van Ghana te gaan werken. De bevindingen van deze studie gaven aan dat artsen ervoor kiezen om in de plattelandsgebieden te werken omdat ze meer vaardigheden en ervaring willen opdoen. Voorts gaven de meeste artsen aan, met name diegenen die aan de School of Medicine and Health Sciences van de University for Development Studies (SMHS-UDS) waren opgeleid, dat hun bachelor-Geneeskunde-curriculum hen goed had voorbereid op het werk op het platteland. Ze gaven echter ook aan dat sociale drempels, toegang tot voorzieningen, geringe loopbaankansen en familiale en culturele overwegingen factoren waren die artsen ervan weerhielden om uit eigen wil in de plattelandsgemeenschappen te gaan werken. Ze deden enkele suggesties voor de verbetering en instandhouding van COBES aan het adres van de overheid en Ministeries van Gezondheid en Onderwijs, zoals het beschikbaar stellen van beurzen aan afgestudeerde basisartsen die graag hun vervolgopleiding in de plattelandsgebieden willen doen. Ook pleitten ze ervoor dat de overheid ervaren artsen en specialisten naar enkele districtsziekenhuizen zendt, zodat het opleidingsprogramma van artsen in deze ziekenhuizen in aanmerking kon komen voor accreditatie.

\section{Hoofdstuk 7}

In Hoofdstuk 7 bespraken we of de voorkeuren van AIOSsen ten aanzien van de locatie van hun vervolgopleiding beïnvloed wordt door het soort curriculum dat in hun opleiding werd gebruikt. De bevindingen lieten zien dat studenten van de Ghana School of Medicine and Dentistry aan de Universiteit van Ghana (UGSMD), ook al hadden zij een beperkt plattelandshulpverleningsprogramma gevolgd als onderdeel van hun opleiding, van mening waren dat het nuttig was om een deel van hun opleiding in de plattelandsgemeenschappen door te brengen. De studenten van de UGSMD gaven echter aan dat zij na hun afstuderen niet in de plattelandsgemeenschappen hadden willen werken als zij tijdens hun studie geen ervaring op het platteland hadden opgedaan. De studenten van de SMHS-UDS waren het ermee eens dat blootstelling aan 
het platteland als onderdeel van het curriculum hen goed voorbereidde op het werk op het platteland na hun afstuderen.

Om het curriculum van de bacheloropleiding Geneeskunde waar COBES een onderdeel van vormt te verbeteren, vroegen de studenten van de UGSMD om de introductie van gemeenschapsgerichte onderwijsactiviteiten zoals plattelandhulpverleningsprogramma's. De studenten van de SHMS-UDS suggereerden echter strategieën ter verbetering van de al bestaande plattelandsprogramma's, zoals het goed voorlichten van studenten over COBES en het kiezen van goed toegeruste en goed geëquipeerde gezondheidscentra.

\section{Hoofdstuk 8}

In Hoofdstuk 8 volgt een algemene discussie van de bevindingen van de diverse studies die een antwoord geven op de in hoofdstuk 1 geformuleerde onderzoeksvragen, waarbij verwezen wordt naar relevante literatuur en uitgelegd wordt hoe deze referenties helpen de onderzoeksvragen te beantwoorden. Vervolgens worden conclusies getrokken, de sterke punten van de studies belicht en de beperkingen van de studies in kaart gebracht. Het Hoofdstuk wordt ten slotte afgesloten met aanbevelingen voor vervolgonderzoek en gevolgen voor de praktijk. 